\title{
Article \\ The Role of Social Capital in Rural Households' Perceptions toward the Benefits of Forest Carbon Sequestration Projects: Evidence from a Rural Household Survey in Sichuan and Yunnan Provinces, China
}

\author{
Lingling Qiu ${ }^{1}$, Weizhong Zeng ${ }^{2}$, Shashi Kant ${ }^{1,3, * \mathbb{C} \text { and Sen Wang }}{ }^{4}$ \\ 1 Institute of Forestry and Conservation, John H. Daniels Faculty of Architecture, Landscape, and Design, \\ University of Toronto, 33 Willcocks Street, Toronto, ON M5S 3B3, Canada; lingling.qiu@mail.utoronto.ca \\ 2 School of Economics \& Southwest Center for Poverty Alleviation and Development Research, \\ Sichuan Agricultural University, \#211 Huimin Road, Chengdu 611130, China; auldkgk@sicau.edu.cn \\ 3 Institute for Management and Innovation, University of Toronto Mississauga, 3359 Mississauga Road, \\ Mississauga, ON L5L 1C6, Canada \\ 4 Freshwater Institute, Fisheries and Oceans Canada, 501 University Crescent, Winnipeg, MB R3T 2N6, Canada; \\ sen.wang@dfo-mpo.gc.ca \\ * Correspondence: shashi.kant@utoronto.ca; Tel.: +1-416-7046-828
}

Citation: Qiu, L.; Zeng, W.; Kant, S.; Wang, S. The Role of Social Capital in Rural Households' Perceptions

toward the Benefits of Forest Carbon Sequestration Projects: Evidence from a Rural Household Survey in Sichuan and Yunnan Provinces, China. Land 2021, 10, 91. https://doi.org/ 10.3390/land10020091

Academic Editor: Prem Raj Neupane Received: 30 November 2020

Accepted: 18 January 2021

Published: 20 January 2021

Publisher's Note: MDPI stays neutral with regard to jurisdictional claims in published maps and institutional affiliations.

Copyright: (c) 2021 by the authors. Licensee MDPI, Basel, Switzerland. This article is an open access article distributed under the terms and conditions of the Creative Commons Attribution (CC BY) license (https:// creativecommons.org/licenses/by/ $4.0 /)$.

\begin{abstract}
We examined the associations between social capital and rural households' perceptions toward social, economic, and environmental benefits of forest carbon sequestration projects by employing the proportional odds model based on data collected from a rural household survey in Sichuan and Yunnan Provinces, China. Results revealed that: (i) households' perceptions toward environmental benefits are more positive than their perceptions toward economic benefits and social benefits, and their perceptions toward economic benefits are more positive than their perceptions toward social benefits; (ii) households having a good relationship with village officials have higher odds of holding more positive perceptions toward social, economic, and environmental benefits of the projects; (iii) households which are members of local associations are more likely to have positive perceptions toward benefits of the projects; (iv) households whose members are more frequently involved in village-level public events are more likely to have more positive perceptions toward benefits of the projects; (v) households having more educated household heads have higher odds of holding better perceptions toward the benefits of FCS projects; and (vi) households of Yunnan Province are less likely to express positive perceptions toward benefits of the projects. Based on the research results, we concluded that social capital is significantly and positively associated with rural households' perceptions toward benefits of forest carbon sequestration projects. Some policy implications are provided regarding how to make use of social capital elements to shape farmers' perceptions toward benefits of the projects for the purpose of achieving a higher level of local acceptability for and sustainability of the projects.
\end{abstract}

Keywords: social capital; forest carbon sequestration; perceptions; benefits; rural households; China

\section{Introduction}

The importance of forest carbon sequestration projects (FCS projects) to climate change mitigation is recognized by the international society. According to the Paris Agreement, conserving forests is considered as a very important instrument to increase carbon sequestration and to reduce the greenhouse effect [1]. In addition, forest carbon sequestration has much poverty alleviation potential in the developing world [2,3]. Implementing FCS projects in poor and forest-rich areas can contribute to income enhancement for local households and thus alleviate poverty [2-5]. Households' perceptions of benefits of FCS projects can influence their willingness to support the sustainable development of these 
projects [6]. Households who have positive perceptions of benefits of FCS projects are more likely to provide support for the development of such projects as compared to households having negative perceptions [6]. Therefore, local households' perceptions toward benefits of FCS projects are considered capable of influencing the sustainable development of these projects in project areas, which indicates that investigating households' perceptions of benefits of FCS projects is of much practical significance to the continuation and sustained development of such projects. Exploring the association between social capital and households' perceptions of benefits of FCS projects is helpful for researchers to understand the hidden drives of household behaviors about their involvement in these projects, and is instrumental for policy makers to improve the future design and implementation of these projects through using policy instruments relating to social capital elements.

Many researchers, including Herreros and Criado [7]; Jones and colleagues [8,9]; Sandanam and colleagues [10]; Ruseva and colleagues [11]; Ziersch and colleagues [12]; Hoogerbrugge and Burge [13]; Jayashankar and Raju [14]; Curry and Holter [15]; Daza [16]; Abrahamowicz [17]; Nowiński and Rialp [18]; Torabi and colleagues [19] and Chen [20] have examined the relationship between social capital and people's perceptions. These studies are primarily focused on the associations between social capital and people's perceptions toward policy implementation; toward immigration; toward entrepreneurial and organizational behaviors; toward education; toward politics, etc. For example, based on face-to-face semi-structured interviews with landholders in Melbourne (Victoria, Australia), Torabi and colleagues highlighted that social capital elements play an important role in easing negative perceptions of landholders and then promoting their participation in biodiverse carbon planting programs/carbon-forestry projects [20]. Jones and colleaguesa and Jones and colleaguesb claimed that social capital is significantly positively associated with people's perceptions of environmental policies [8,9]. They investigated the association between social capital and people's perceptions of general environmental policies, which provided us with empirical support for the examination of social capital influence on specific conservation projects such as the FCS projects.

As reviewed above, despite that there is empirical evidence for the relationship between social capital and people's perceptions toward environmental programs, none of the relevant studies is focused on the association between social capital and rural households' perceptions toward benefits of FCS projects. Thereby our study intends to add to the existing research body by empirically examining the association between social capital and rural households' perceptions toward benefits of FCS projects based on data from a rural household survey in Sichuan and Yunnan Provinces (China). Because costs and benefits of agricultural and forestry projects are commonly categorized into social, economic, and environmental dimensions [6,21-24], we investigate rural households' perceptions toward social, economic, and environmental benefits of FCS projects. Based on data collected from 450 rural households, our study uses proportional odds model as the statistical method to examine the relationship between social capital and rural households ${ }^{\prime}$ perceptions toward social, economic, and environmental benefits of FCS projects. In this paper, we address two research questions: (i) Are local households' perceptions about social, economic, and environmental benefits of FCS projects different? and (ii) What is the relationship between social capital and rural households' perceptions toward social, economic, and environmental benefits of FCS projects? Our research results are expected to contribute to policy interventions which will make use of social capital elements to shape local farmers' perceptions toward benefits of FCS projects and desirably make FCS projects more acceptable and sustainable in local communities.

The rest of this paper is organized as follows. Section 2 presents the theoretical framework, followed by an introduction of FCS projects in Sichuan and Yunnan. Following is the methodology composed of data collection, variables, and data analyses. And results and discussion are provided after the methodology. The last section shows the concluding remarks. 


\section{Theoretical Framework}

Social capital is the aggregate of social resources which are shared and available among a community [25]. Social capital is also considered as a social-structural resource which is composed of some elements of a social structure and facilitates some actions of individuals who are within the structure [26]; the structure may be in the forms of networks, trust and norms which enable members to act together more effectively to pursue common objectives [27]. Similar to other forms of capital such as human capital and physical capital, social capital is productive, making possible the achievement of certain ends which would not be attainable in its absence [26]. However, Coleman proposed that what makes social capital different from other forms of capital is that social capital inheres in the structure of relations among persons, lodged neither in individuals nor in physical instruments of production [26]. Social capital, therefore, is most intangible as compared to physical capital and human capital.

Due to its inherent content of peoples' relations, social capital is believed to have associations with peoples' perceptions, behaviors, performance and outcomes. People who have more social capital tend to be more proactive and thus have easier access to more productive resources and consequently earn a higher level of income [4]. Back in 1990s, research by Putnam revealed the powerful impact of social capital on the performance of government and other social organizations [28]. Specifically, Putnam concluded that civic engagement in community affairs, termed as one essential component of social capital, significantly influences performance of government and social institutions [28]. As a valuable intangible asset, social capital is also playing an increasingly important role in entrepreneurial performances [29]. Because human beings tend to take actions based on what they perceive, perceptions are considered to have a direct and pervasive impact on behaviors [30]. Hence, figuring out the association between social capital and perceptions is instinctively more than necessary to reveal how social capital influences people' behaviors and subsequently the resulting performances and outcomes.

According to Scrivens and Smith's study which built on the work of Bourdieu, Coleman, and Putnam, social capital is classified into four categories including personal relationships, social network support, civic engagement, trust and cooperative norms [31]. Personal relationships and civic engagement mainly refer to network structures and activities, while social network support and trust and cooperative norms are identified as productive resources. As personal relationships and civic engagement are highly emphasized and commonly used as social capital elements in rural studies [32-38], we select social capital measurements based on these two dimensions.

Following the definition of social capital, we define the term "perception". As revealed by Oatley's research, actual perception involves both "bottom up" and "top down" operations [39]. The "bottom up" operation starts from the elements in the lowest domains (e.g., the sensory input such as what the perceiver sees, hears, and touches), and gradually works up towards more and more complex interpretations; The "top down" operation relates to the perceiver's prior-formulated expectations of the sensory input, and represents how the sensory information is interpreted. Distinct from attitude which represents people's action tendencies to an object, perception represents the meaning attributed to an object [40]. The difference in the respective definitions of attitude and perception implies that people may develop their action tendencies to an object based on their impression on or knowledge about the object, whereas they may attribute meaning to an object without necessarily having knowledge about it. That is, people may simply attribute meaning to an object based on their received sensory input such as what they see, hear, or touch, which to some degree makes it less restrictive to study perception. Practically, it is quite possible that not all households in the FCS project area have capacity to access knowledge about such projects, which to some degree makes it challenging to elicit their attitudes toward the projects. Considering the rural reality, we focus on perception rather than attitude as less restrictions of eliciting perceptions indicate higher odds of survey success. Perception can only be measured indirectly in the form of inference. For instance, local households' 
perceptions toward economic benefits of FCS projects can only be inferred by their answers to questions relating to the economic benefits.

Referring to the existing research which identified an association between social capital and perceptions [7-19], we in our study hypothesize that personal relationships and civic engagement as social capital elements are associated with rural households' perceptions toward benefits of FCS projects. There are two major reasons why we choose personal relationships and civic engagement as social capital elements used in our study: (i) the first reason has been addressed in the above text which states that many studies of rural households use personal relationships and civic engagement as social capital representations; (ii) the other reason is that the survey design predominantly includes questions relating to household-level factors as we intend to collect the household-level data, which inevitably neglects community-level elements in terms of the representation of social capital. More specifically, we speculate that households having good interpersonal relationships and active civic engagement tend to have positive perceptions toward benefits of FCS projects. For instance, households who get along well with neighborhoods and village officials are more likely to be optimistic toward their lives, and thus are more likely to have positive perceptions toward benefits of FCS projects. Likewise, households actively involved in village-level public affairs tend to gain more comprehensive knowledge about the FCS projects and consequently more likely develop positive perceptions toward the projects. As such, we theoretically claim that social capital is positively associated with households' perceptions toward benefits of FCS projects, which will further be confirmed through empirical examination by our study. In addition to social capital elements, some other possible factors may also influence households' perceptions toward benefits of FCS projects, such as age $[12,13,19]$, gender and educational attainment $[7,8,12,13,16,19]$, power, and geographic locations. These possible influencing factors were identified either by literature overview or through focus group discussions with local households, which will be further discussed in the variables section. As discussed, a chart is presented to showcase the influencing factors of households' perceptions toward benefits of FCS projects (Figure 1).

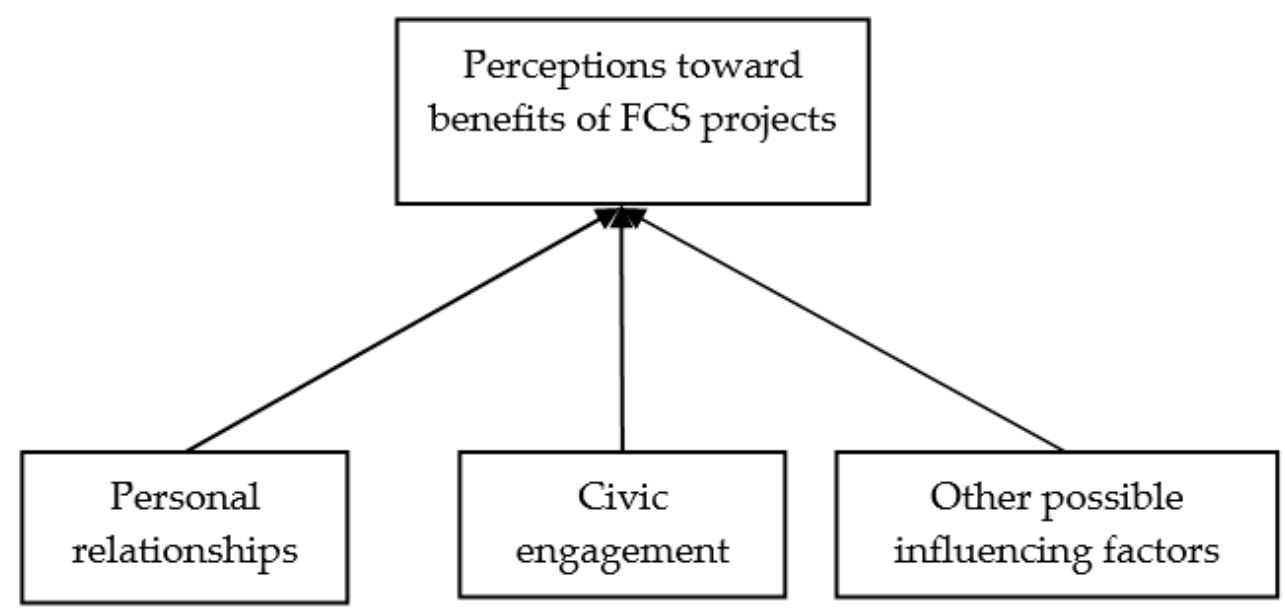

Figure 1. A model of households' perceptions toward benefits of FCS projects.

\section{FCS Projects in Sichuan and Yunnan}

The study sites cover the project areas of two FCS projects-The Novartis Sichuan Forestry Project (also called Novartis Sichuan Climate, Community and Biodiversity Project) in Sichuan Province and a multiple-benefit forest project which also follows the Climate, Community, and Biodiversity Standards (CCB Standards) in Yunnan Province.

The Novartis Sichuan Forestry Project (NSF Project) was initiated by Novartis (a Swiss pharmaceutical company) in 2010 and was validated to the CCB Standards in 2013. The CCB 
Standards were developed by the Climate, Community \& Biodiversity Alliance (CBBA), which are the leading social and environmental standards for land-based carbon projects, aimed at generating significant climate, community, and biodiversity benefits [41-43]. These Standards identify projects which simultaneously address climate change, support local communities, and conserve biodiversity; promote excellence and innovation in project design and implementation; and mitigate risk for investors, offset buyers, and increase funding opportunities for project developers [43]. The NSF Project was expected to achieve three goals, which were respectively mitigating climate change through carbon sequestration, improving the income of local households, and enhancing biodiversity. Also, in 2013, it was registered as a Clean Development Mechanism Afforestation and Reforestation Project (CDM A\&F Project) under United Nations Framework Convention for Climate Change (UNFCCC), which makes it the second registered CDM carbon-sink forestry project and the largest one in Sichuan Province, China [41,42].

The NSF Project period is thirty years, and project areas are located in five countiesGanluo, Yuexi, Meigu, Zhaojue, and Leibo-of Liangshan Yi Autonomous Prefecture in Sichuan Province. Plantation was completed in 2018, and it was done on the deforested land under clear tenure holdings. The participating entities of the project and their responsibilities are as follows: Novartis Pharmacy Switzerland and Novartis China are the project investor; Shanshui Conservation Center is the technology provider for the project; Forest departments at the national and provincial levels take responsibilities for the project supervision; Forest departments at the county level are the project implementers; Sichuan Daduhe Forestation Bureau is the project developer; Yi ethnic minority communities are participants in the plantation and forest management practices. Novartis Pharmacy Switzerland and Novartis China were expected to provide $65 \%$ project funds and the remaining $35 \%$ were supposed to be funded by the forest departments of Sichuan Province [44]. According to the project design document, first verification and credit issuance of carbon will take place in 2025. The lands on which the project is implemented are distributed in forty-nine villager groups of five participating counties. The project is expected to benefit 4265 rural households, most of which are comprised of Yi people that overlap an overwhelmingly large number of poor populations.

The forest carbon sequestration project of Yunnan Province is a multiple-benefit forest project which follows the CCB Standards. Similar to the project in Sichuan Province, it is an afforestation and reforestation project. It was initiated in 2005. The purposes of this project were to achieve compensation for ecological benefits through carbon transactions, to increase community income while protecting biodiversity, and to urge community residents to restore and protect forests. The project was jointly implemented by the National Forestry Bureau (now National Administration of Forestry and Grassland), Conservation International (CI), The Nature Conservancy (TNC), and the Department of Forestry of Yunnan Province (now Department of Forestry and Grassland of Yunnan Province). The project area includes the counties of Tengchong, Jinghong, Menghai and Mengla. Forest land used for the project was converted from agricultural land and grassland, aiming to create 467.6 hectares of high-quality forest. According to the project design document, the project was expected to involve and benefit 433 rural households/2108 farmers; local households in the project area were primarily involved in tree plantation and forest patrolling and protection activities.

\section{Methodology}

\subsection{Data Collection}

Data were collected through a household questionnaire survey of rural households participating in the two FCS projects (see Supplementary Material). Prior to the household survey, we conducted a focus group discussion (FGD) to assist in the design of questionnaire. FGD participants were composed of adult representatives from different participating households, selected from different age cohorts and groups with different levels of educational attainment. After the FGD, we completed the design of questionnaire. 
To test and refine the questionnaire, we also conducted a small-scale pre-survey with $\sim 20$ households in Yuexi County. Based on the feedback of the pre-survey, the questionnaire was finalized and then used for the formal household survey. For the household survey, we used a random sampling method to select households. In each Province, we randomly selected two counties-Ganuo and Yuexi-in Sichuan Province, and the counties of Tengchong and Jinghong in Yunnan Province (see Figure 2). Next, we randomly selected 2-3 towns in each county, and 1-2 villages in each town. Finally, $50 \%$ households participating in the respective projects were selected from each selected village for survey. The survey data were collected at the household level instead of the individual level. On behalf of their households, one adult member in each household was interviewed. However, all interviewees were free and were encouraged to obtain the information from other family members. The sample villages are located in ethnic minority areas, and therefore local college students were employed as translators to overcome communication barriers. Totally 450 rural households were interviewed, 180 in Sichuan Province and 270 in Yunnan Province. We received usable data from 367 households, attaining a response rate of 81.56 percent. The questionnaire has three parts: (i) questions related to the measurement of perceptions toward economic, social, and environmental benefits; (ii) questions to measure social capital; and (iii) questions related to sociodemographic variables. Details of these variables and measurements are discussed next.

\section{Locations of the study sites}

\section{Legend}
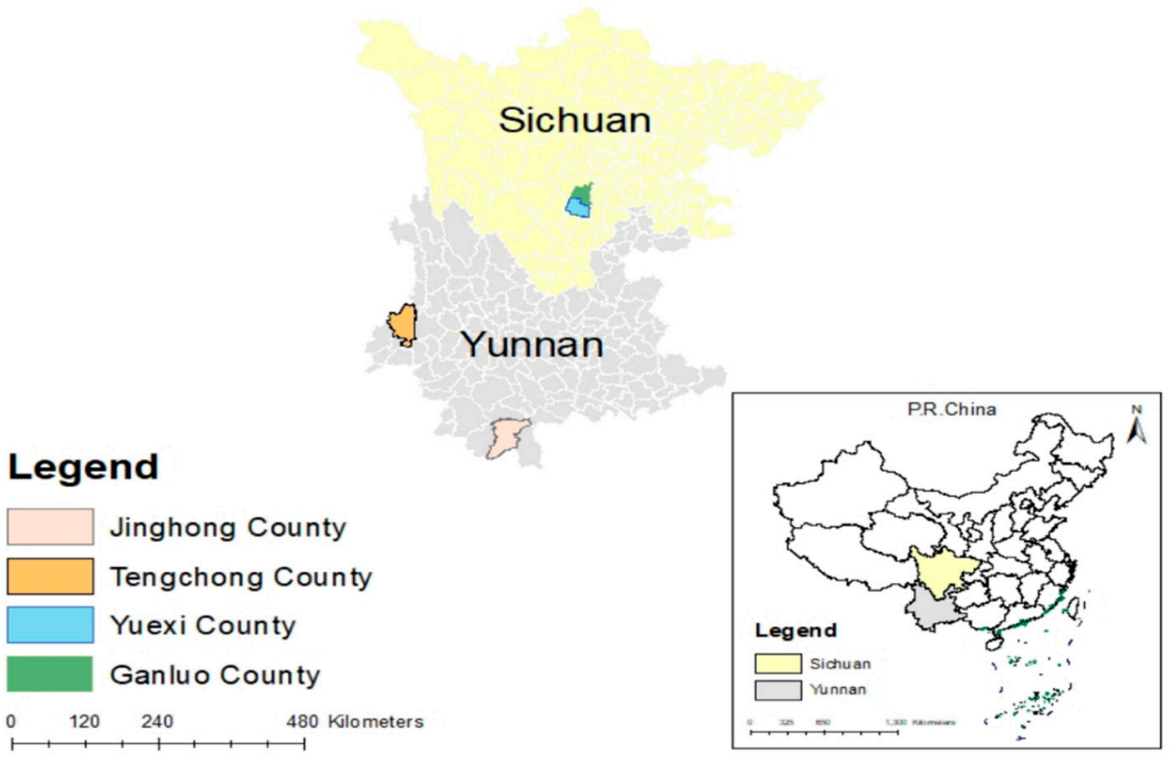

Figure 2. A map of locations of the study sites.

\subsection{Variables}

\subsubsection{Dependent Variables-Erceptions about Benefits}

Respondents' perceptions toward economic, social, and environmental benefits of the FCS projects were measured by a set of questions for each type of benefit. The subject of questions was composed of wage income from participation in the project, income from renting/transferring land to the project, returns from harvesting non-timber forest products, and enhancement of overall income for economic benefits; overall life satisfaction, learning of new skills, enrichment of life, fulfillment by supporting the project, and awareness about ecological protection for social benefits; and improved air quality, enhanced biodiversity, decrease in natural disasters, and increased forest cover for environmental benefits. Every 
question was framed in terms of a statement and participants were asked to indicate their response on a 5-point Likert scale ranging from strongly disagree (1) to strongly agree (5).

\subsubsection{Independent Variables-Social Capital}

As defined by Scrivens and Smith, personal relationships refer to the structure and nature of people's personal networks, concerned with the connections between people who know each other in one way or another [31]. In our study, we used two variablesrelationship with neighbors (RELWNHB) and relationship with village officials (RELWVOF) as measures of personal relationships. Both personal relationship variables were measured using a 5-point Likert scale ranging from 1 (very bad) to 5 (very good).

As per Scrivens and Smith, "Civic engagement refers to actions and behaviors that can be seen as contributing positively to the collective life of a community or society, as well as to the characteristics of these civic networks themselves" [31]. Hence to measure civic engagement, we used two variables-membership in local associations (MEMASSO), and involvement in village public events on a yearly basis (INVPUBE). Membership in local associations is measured by a binary scale- 1 means the sample household is a member of local associations/organizations and 0 meaning it is not a member. Involvement in village public events on a yearly basis is a numerical variable which takes different values to indicate the frequency of sample households' involvement in village public events. The rubric of all four social capital variables is such that larger the value of the variable higher is the social capital.

\subsubsection{Other Covariates}

In addition to social capital variables, some covariates are also selected for the modelling procedure. These covariates are composed of gender of the household head (GENDER), age of the household head (AGE), years of schooling of the household head (YRSCHOL), the political power of the household (POPOWER), and the province dummy (DUMPROV). Gender of the household head is a categorical variable that has two categories male and female; we use value 1 for denoting male and 0 for female. Age of the household head and years of schooling of the household head are numerical variables. The political power of the household is interpreted via whether there is at least one elected village official in the family, which takes value 1 if the investigated household has at least one village official and 0 otherwise. The province dummy takes the value 1 for Yunnan Province and value 0 for Sichuan Province. Abbreviations used, measurement scale, and descriptive statistics of all variables are presented in Table 1.

Table 1. Descriptions of variables.

\begin{tabular}{|c|c|c|c|c|}
\hline Variables & Meaning & Measurement Scale & Mean & Std.Dev \\
\hline PERSOCB & Respondents' perceptions of social benefits & 5-point Likert Scale & 2.97 & 0.78 \\
\hline PERECOB & Respondents' perceptions of economic benefits & 5-point Likert Scale & 3.09 & 0.71 \\
\hline PERENVB & Respondents' perceptions of environmental benefits & 5-point Likert Scale & 3.24 & 0.70 \\
\hline RELWNHB & Relationship with neighbors & 5-point Likert Scale & 3.16 & 1.18 \\
\hline RELWVOF & Relationship with village officials & 5-point Likert Scale & 3.92 & 0.85 \\
\hline MEMASSO & Membership in local organizations & Binary Scale $(1=$ yes; $0=$ no $)$ & 0.55 & 0.50 \\
\hline INVPUBE & Involvement in village public events on a yearly basis & Cardinal Scale & 4.35 & 2.17 \\
\hline GENDER & Gender of the household head & Binary scale (Male $=1$; female $=0$ ) & 0.93 & 0.25 \\
\hline AGE & Age of the household head & Years & 46.67 & 11.33 \\
\hline YRSCHOL & Years of schooling of the household head & Years & 4.93 & 2.48 \\
\hline POPOWER & Political power of the household & Binary Scale $(1=$ yes; $0=$ No $)$ & 0.11 & 0.31 \\
\hline DUMPROV & Province dummy & $1=$ Yunnan; $0=$ Sichuan & 0.71 & 0.46 \\
\hline
\end{tabular}

Notes: 5-point Likert scale is specified as Very negative $/ \mathrm{bad}=1$; Relatively negative $/ \mathrm{bad}=2$; Neutral $=3$; Relatively positive $/$ good $=4$; Very positive/good = 5; Means and Std.Devs are computed using Stata 14.0. 


\subsection{Data Analysis}

Data analysis included three steps: (i) construction of indices for perceptions; (ii) analysis of variations in perceptions toward economic, social, and environmental benefits, and (iii) modeling of perceptions toward economic, social, and environmental benefits. These steps are discussed next.

In the first step, we construct indices for perceptions of economic, social, and environmental benefits of the FCS projects. We have four questions each for economic and environmental benefits, and five questions for social benefits. Hence, to construct a comparable measure of all three types of benefits, we use two stage process. In the first stage, we add numerical values of answers to each question related to the benefit. In the second stage, we transform the indexes for three types of perceptions into three ordinal categorical variables with each having five response levels including very negative $(1 \leq$ values $\leq 5$ for perceptions of social benefits; $1 \leq$ values $\leq 4$ for perceptions of economic and environmental benefits), relatively negative ( $6 \leq$ values $\leq 10$ for perceptions of social benefits; $5 \leq$ values $\leq 8$ for perceptions of economic and environmental benefits), neutral (11 $\leq$ values $\leq 15$ for perceptions of social benefits; $9 \leq$ values $\leq 12$ for perceptions of economic and environmental benefits), relatively positive ( $16 \leq$ values $\leq 20$ for perceptions of social benefits; $13 \leq$ values $\leq 16$ for perceptions of economic and environmental benefits), and very positive ( $21 \leq$ values $\leq 25$ for perceptions of social benefits; $17 \leq$ values $\leq 20$ for perceptions of economic and environmental benefits). For the econometric modelling purpose, three dependent variables (perceptions about economic, social, and environmental benefits) have five response levels, 1 = very negative, 2 = relatively negative, $3=$ neutral, $4=$ relatively positive, $5=$ very positive.

In the second step, we conduct a simple comparative analysis of respondents' perceptions toward social, economic, and environmental benefits to test whether respondents have different levels of perceptions with three types of benefits. Since we converted rural households' perceptions into five categorical levels, we use non-parametric tests such as Friedman and Wilcoxon signed-rank tests.

In the third step, we estimate econometric models of the households' perceptions toward social, economic, and environmental benefits to find relationships between these perceptions and the elements of social capital. Since each dependent variable has five ordered response categories, ordinal logistic regression is preferable to the multinomial logistic regression due to its preservation of the ordering information. The ordinal logistic regression models the relationship between a set of predictors (explanatory variables) and an ordinal response variable (the dependent variable). In this paper, the proportional odds model is used, which is one category of ordinal logistic models. The proportional odds model, also called the constrained cumulative logit model, compares the probability of an equal or smaller response with the probability of a larger response. Because there are three dependent variables in our study, we present three equations as follows:

$$
\begin{aligned}
& \operatorname{logit}\left[P\left(\text { PERSOCB }_{i} \leq j \mid \boldsymbol{x}_{i}\right)\right]=\log \left[\frac{P\left(\text { PERSOCB }_{i} \leq j \mid \boldsymbol{x}_{i}\right)}{P\left(\operatorname{PERSOC} B_{i}>j \mid \boldsymbol{x}_{i}\right)}\right]=\alpha_{\text {socj }}-\boldsymbol{\beta}_{s o c}^{\prime} \boldsymbol{x}_{i}, j=1,2,3,4 . \\
& \operatorname{logit}\left[P\left(P E R E C O B_{i} \leq j \mid x_{i}\right)\right]=\log \left[\frac{P\left(P E R E C O B_{i} \leq j \mid x_{i}\right)}{P\left(P E R E C O B_{i}>j \mid x_{i}\right)}\right]=\alpha_{e c o j}-\beta_{e c o}^{\prime} \boldsymbol{x}_{i}, j=1,2,3,4 . \\
& \operatorname{logit}\left[P\left(P E R E N V B_{i} \leq j \mid x_{i}\right)\right]=\log \left[\frac{P\left(P E R E N V B_{i} \leq j \mid x_{i}\right)}{P\left(\operatorname{PERENV} B_{i}>j \mid \boldsymbol{x}_{i}\right)}\right]=\alpha_{\text {envj }}-\boldsymbol{\beta}_{\text {env }}^{\prime} \boldsymbol{x}_{i}, j=1,2,3,4 .
\end{aligned}
$$

where $\beta_{\text {soc }}, \beta_{\text {eco }}$ and $\beta_{\text {env }}$ denote vectors of regression coefficients, values of regression coefficients being constant across the logits or response levels. $\beta^{\prime}$ represents a transpose of the coefficient vector. $x_{i}$ denotes the vector of nine explanatory variables for observation $i$. The negative signs of $\boldsymbol{\beta}_{s c c}^{\prime} \boldsymbol{x}_{i}, \boldsymbol{\beta}_{\text {eco }}^{\prime} \boldsymbol{x}_{i}$ and $\boldsymbol{\beta}_{\text {env }}^{\prime} \boldsymbol{x}_{i}$ are included to allow for the usual interpretation that positive values of $\beta_{s o c}, \beta_{\text {eco }}$ and $\beta_{\text {env }}$ mean that as $x$ increases, the probabilities of higher values of PERSOCB, PERECOB and PERENVB also increase. 
As demonstrated by Equations (1)-(3), independent variables in these equations are the same despite different dependent variables. Equations (1)-(3) will also be estimated based on the same data set collected from the household survey. Because regression coefficients are invariant with response levels, the influence of a specific explanatory variable on the response variable can be described by a single coefficient (i.e., in the equations above the effects of $n$th explanatory variable $x_{n}$ on all response levels can be indicated by $\beta_{\text {soc } \_} x_{n}$, $\beta_{\text {eco_ } x_{n}}$ and $\left.\beta_{\text {env } \_} x_{n}\right)$. For instance, when $x_{n}$ is one of the ordinal categorical explanatory variables as coded in the variables section, we can make interpretations of coefficients of $x_{n}$ as follows:

$$
\begin{aligned}
\mathrm{e}^{\beta_{\text {soc } \_x_{n}}} & =\frac{P\left(\text { PERSOCB }>j \mid x_{n}=2\right) / P\left(P E R S O C B \leq j \mid x_{n}=2\right)}{P\left(P E R S O C B>j \mid x_{n}=1\right) / P\left(P E R S O C B \leq j \mid x_{n}=1\right)}, j=1,2,3,4 . \\
\mathrm{e}^{\beta_{\text {eco_ } x_{n}}} & =\frac{P\left(P E R E C O B>j \mid x_{n}=2\right) / P\left(P E R E C O B \leq j \mid x_{n}=2\right)}{P\left(P E R E C O B>j \mid x_{n}=1\right) / P\left(P E R E C O B \leq j \mid x_{n}=1\right)}, j=1,2,3,4 . \\
\mathrm{e}^{\beta_{\text {env_ } x_{n}}} & =\frac{P\left(P E R E N V B>j \mid x_{n}=2\right) / P\left(P E R E N V B \leq j \mid x_{n}=2\right)}{P\left(P E R E N V B>j \mid x_{n}=1\right) / P\left(P E R E N V B \leq j \mid x_{n}=1\right)}, j=1,2,3,4 .
\end{aligned}
$$

To make the above exponentiated coefficients more understandable, a numerical instance is provided. For example, if the regression coefficient of neighborhood relationship in the economic benefits perception equation is 0.1234 , then its exponentiated value is 1.1313 $\left(e^{0.1234}=1.1313\right)$. In the statistical sense, the exponentiated coefficient can be interpreted in such a way that compared with a household having a good relationship with neighbors, a household having a very good neighborhood relationship (one level higher than a good relationship) is 1.1313 times more likely to hold a more positive perception toward economic benefits of the FCS project.

Prior to estimating the econometric model, we compute variance inflation factors (VIFs) between all explanatory factors to test for harmful multicollinearity. According to the rule of thumb, VIFs values equal to or larger than 10 may be a concern for multicollinearity $[45,46]$.

\section{Results and Discussion}

The questionnaire was distributed to 450 households (180 in Sichuan and 270 in Yunnan). We received usable data from 367 households, attaining a response rate of 81.56 percent. The mean values and standard deviations for all variables are given in Table 1. The frequencies of different response levels for the perceptions toward social, economic, and environmental benefits are given in Table 2. As indicated in Table 2, a larger proportion (25.34\%) indicated relatively negative perception about social benefits compared to environmental benefits (11.99\%) and economic benefits (17.71\%). Similarly, a larger proportion $(29.15 \%)$ indicated relatively positive perception about environmental benefits compared to social benefits (16.62\%) and economic benefits (20.98\%). A very large

\begin{tabular}{|c|c|c|c|c|c|c|}
\hline \multirow{2}{*}{ Response Levels } & \multicolumn{2}{|c|}{ Perceptions of Social Benefits } & \multicolumn{2}{|c|}{ Perceptions of Economic Benefits } & \multicolumn{2}{|c|}{ Perceptions of Environmental Benefits } \\
\hline & Frequency & Percentage & Frequency & Percentage & Frequency & Percentage \\
\hline Very negative & 3 & $0.82 \%$ & 0 & $0 \%$ & 0 & $0 \%$ \\
\hline Relatively negative & 93 & $25.34 \%$ & 65 & $17.71 \%$ & 44 & $11.99 \%$ \\
\hline Neutral & 196 & $53.41 \%$ & 214 & $58.31 \%$ & 204 & $55.59 \%$ \\
\hline Relatively positive & 61 & $16.62 \%$ & 77 & $20.98 \%$ & 107 & $29.15 \%$ \\
\hline Very positive & 14 & $3.81 \%$ & 11 & $3.00 \%$ & 12 & $3.27 \%$ \\
\hline
\end{tabular}
proportion of respondents' perceptions were neutral for all three types of benefits.

Table 2. Frequencies of different response levels of perceptions.

Note: The numbers above are calculated by authors based on the household survey data. 
The mean response levels for all three perceptions and two Provinces are given in Table 3. The response levels of perceptions being ordinal, we used the Friedman test to check statistically significant difference between mean response levels of perceptions for each Province, results presented in columns (1)-(3). The Friedman test results indicate that the mean response levels for three categories of benefits, for both Provinces separately and together, are significantly different at $1 \%$ significance level.

Table 3. Mean response levels for social, economic, and environmental benefits by province.

\begin{tabular}{lccccc}
\hline & (1) Friedman Test & (2) Friedman Test & (3) Friedman Test & $\begin{array}{c}\text { (4) Pairwise } \\
\text { Wilcoxon } \\
\text { Signed-Rank } \\
\text { Test }\end{array}$ & $\begin{array}{c}\text { (5) Pairwise } \\
\text { Wilcoxon } \\
\text { Signed-Rank } \\
\text { Test }\end{array}$ \\
\hline Social Benefits & $\begin{array}{c}\text { Economic } \\
\text { Benefits }\end{array}$ & $\begin{array}{c}\text { Environmental } \\
\text { Benefits }\end{array}$ & $\begin{array}{c}\text { Social Benefits } \\
\text { Test }\end{array}$ & $\begin{array}{c}\text { Environmental } \\
\text { Benefits }\end{array}$ & $\begin{array}{c}\text { Economic } \\
\text { Benefits }\end{array}$ \\
\hline Sichuan Province & $3.06^{* *}$ & $3.19^{* *}$ & $3.33^{* *}$ & $-2.23^{*}$ & -1.52 \\
\hline Yunnan Province & $2.94^{* *}$ & $3.05^{* *}$ & $3.20^{* *}$ & $-2.33^{*}$ \\
\hline Both Provinces & $2.97^{* *}$ & $3.09^{* *}$ & $3.24^{* *}$ & $-3.14^{* *}$ & $-6.33^{* *}$ \\
\hline
\end{tabular}

Notes: Values in the table are calculated using Stata 14.0; the stars indicate the significant levels of differences in mean response levels between social benefits and other benefits in column (1), between economic benefits and other benefits in column (2), between environmental benefits and other benefits in column (3), between social benefits and economic benefits in column (4), between social benefits and environmental benefits in column (5), and between economic benefits and environmental benefits in column (6); ${ }^{* *}$ and * indicate significance at $1 \%$ and $5 \%$, respectively; values in columns (1)-(3) are values of mean response levels of perceptions toward each benefit for the Friedman test, while values in columns (4)-(6) are Z values for the pairwise Wilcoxon signed-rank test.

The mean values of response levels, presented in Table 3, also indicate that the mean response levels for perceptions toward environmental benefits are higher than perceptions of economic benefits which are higher than mean response levels of social benefits for both Provinces separately and combined. To test the statistical significance of differences between perceptions toward social and economic benefit, between perceptions toward economic \& environmental benefits, and between perceptions toward social \& environmental benefits, we use the pairwise Wilcoxon signed-rank test. The test results are given in columns (4)-(6) of Table 3. The results reveal that response levels for economic benefits and environmental benefits are both statistically significantly higher than response levels for social benefits for Sichuan, Yunnan, and both Provinces together. Similarly, response levels for environmental benefits are statistically significantly higher than economic benefits for Yunnan and both Provinces together, but that is not the case for Sichuan Province.

The estimation results of econometric model are given in Table 4. All VIFs values among independent variables are smaller than 10, which means that multicollinearity is not an issue which negatively impacts the estimation results. The results indicate that the coefficient of relationship with neighbors (RELWNHB) is positive but not statistically significant for any of the three benefits. However, the coefficients of all other three elements of social capital ((relationship with village officials (RELWVOF), membership in local associations (MEMASSO) and involvement in village public events (INVPUBE)) are positive and statistically significant for all three categories of benefits. In the case of the covariates, the coefficient of years of schooling of the household head (YRSCHOL) is positive and significant for all three types of benefits while the coefficients of remaining three variables (gender, age and political power of the household) are not significant for any of the three benefits. The negative values of provincial dummy variable (DUMPROV) (significant for economic and environmental benefits) indicate that households of Yunnan Province are more likely to have negative perceptions about economic and environmental benefits as compared to respondents of Sichuan Province.

The statistically significant different values of the coefficients of relationship with village officials (RELWVOF), membership in local associations (MEMASSO), and involvement in public events (INVPUBE) in the equations of three types of benefits provide some interesting insights. For example, the coefficient of RELWVOF is highest (0.4819) for the 
perception toward economic benefits and the lowest (0.2874) for the perception toward environmental benefits. The RELWVOF coefficient's value of 0.4819 for economic benefits indicates that the estimated odds ratio of a respondent reporting one level higher (positive) perception about economic benefits with a change of one level in the relationships with village officials (i.e., change from 1 to 2 or 2 to 3 etc.) is $1.6191\left(\mathrm{e}^{0.4819}=1.6191\right)$ while the estimated odds ratio for environmental benefits is $1.3330\left(\mathrm{e}^{0.2874}=1.3330\right)$. In other words, households whose family members have a good relationship with village officials have higher odds of holding better perceptions about three categories of benefits, and these odds for economic and social benefits are quite high as compared to odds for environmental benefits. In essence, a good relationship with village officials influences positively households ${ }^{\prime}$ perceptions about three types of benefits, and the magnitude of the influence is the highest on the perceptions toward economic benefits and the lowest on the perceptions toward environmental benefits. Similarly, membership in local associations and involvement in public events influence positively households' perceptions about three types of benefits; and the ranking (in decreasing order) of the magnitude of the influence of both elements is perceptions about environmental benefits, social benefits, and economic benefits. In other words, both measures of civic engagement have positive influences on perceptions toward all three benefits; the highest influence is on perceptions about environmental benefits and the lowest on perceptions about economic benefits.

Table 4. Regression results.

\begin{tabular}{|c|c|c|c|c|c|c|c|c|c|}
\hline \multirow{2}{*}{ Variables } & \multicolumn{2}{|c|}{ Equation (1) Social Benefits } & \multicolumn{2}{|c|}{$\begin{array}{c}\text { Equation (2) Economic } \\
\text { Benefits }\end{array}$} & \multicolumn{2}{|c|}{$\begin{array}{c}\text { Equation (3) } \\
\text { Environmental Benefits }\end{array}$} & \multirow{2}{*}{$\begin{array}{c}\text { Dif. of Coef. } \\
\text { between } \\
\text { Equations } \\
\text { (1) and (2) }\end{array}$} & \multirow{2}{*}{$\begin{array}{l}\text { Dif. of Coef. } \\
\text { between } \\
\text { Equations } \\
\text { (1) and (3) }\end{array}$} & \multirow{2}{*}{$\begin{array}{l}\text { Dif. of Coef } \\
\text { between } \\
\text { Equations } \\
\text { (2) and (3) }\end{array}$} \\
\hline & Coef. & Exp. & Coef. & Exp. & Coef. & Exp. & & & \\
\hline RELWNHB & $\begin{array}{c}0.1054 \\
(0.0906)\end{array}$ & 1.1112 & $\begin{array}{l}0.0692 \\
(0.094)\end{array}$ & 1.0717 & $\begin{array}{c}0.1260 \\
(0.0979)\end{array}$ & 1.1343 & - & - & - \\
\hline RELWVOF & $\begin{array}{l}0.4318^{* * *} \\
(0.1378)\end{array}$ & 1.5400 & $\begin{array}{c}0.4819^{* * *} \\
(0.1491)\end{array}$ & 1.6191 & $\begin{array}{l}0.2874^{*} \\
(0.1555)\end{array}$ & 1.3330 & $-0.0501^{* * *}$ & $0.1444^{* * *}$ & $0.1945^{* * *}$ \\
\hline MEMASSO & $\begin{array}{l}0.6858 * * \\
(0.2821)\end{array}$ & 1.9854 & $\begin{array}{l}0.5475 * \\
(0.3016)\end{array}$ & 1.7289 & $\begin{array}{l}0.8135 * * \\
(0.3392)\end{array}$ & 2.2558 & $0.1383^{* * *}$ & $-0.1277^{* * *}$ & $-0.2660^{* * *}$ \\
\hline INVVPUBE & $\begin{array}{c}0.4049 * * * \\
(0.0607)\end{array}$ & 1.4992 & $\begin{array}{l}0.3501 * * * \\
(0.0697)\end{array}$ & 1.4192 & $\begin{array}{l}0.5101^{* * *} \\
(0.0691)\end{array}$ & 1.6655 & $0.0548^{* * *}$ & $-0.1052^{* * *}$ & $-0.1600^{* * *}$ \\
\hline GENDER & $\begin{array}{c}0.0737 \\
(0.4327)\end{array}$ & 1.0765 & $\begin{array}{c}0.3810 \\
(0.3758)\end{array}$ & 1.4637 & $\begin{array}{c}0.3011 \\
(0.3996)\end{array}$ & 1.3513 & - & - & - \\
\hline AGE & $\begin{array}{c}0.0022 \\
(0.0085)\end{array}$ & 1.0022 & $\begin{array}{c}0.0124 \\
(0.0096)\end{array}$ & 1.0125 & $\begin{array}{l}-0.0001 \\
(0.0092)\end{array}$ & 0.9999 & - & - & - \\
\hline YRSCHOL & $\begin{array}{l}0.1890 * * * \\
(0.0543)\end{array}$ & 1.2080 & $\begin{array}{l}0.1896^{* * *} \\
(0.0617)\end{array}$ & 1.2088 & $\begin{array}{l}0.1425^{* * *} \\
(0.0521)\end{array}$ & 1.1532 & -0.0006 & $0.0465^{* * *}$ & $0.0471^{* * *}$ \\
\hline POPOWER & $\begin{array}{l}-0.4719 \\
(0.3591)\end{array}$ & 0.6238 & $\begin{array}{c}0.0298 \\
(0.3849)\end{array}$ & 1.0302 & $\begin{array}{l}-0.5097 \\
(0.3664)\end{array}$ & 0.6007 & - & - & - \\
\hline DUMPROV & $\begin{array}{l}-0.3473 \\
(0.2276)\end{array}$ & 0.7066 & $\begin{array}{c}-0.4586^{*} \\
(0.2353)\end{array}$ & 0.6322 & $\begin{array}{c}-0.4002 * \\
(0.2362)\end{array}$ & 0.6702 & - & - & $0.0584^{* * *}$ \\
\hline $\begin{array}{l}\text { Constant } \\
\text { cut1 }\end{array}$ & $\begin{array}{l}-0.9745 \\
(1.0064)\end{array}$ & - & $\begin{array}{c}3.3161^{* * *} \\
(0.8889)\end{array}$ & - & $\begin{array}{l}1.8454^{* *} \\
(0.8133)\end{array}$ & - & - & - & - \\
\hline $\begin{array}{l}\text { Constant } \\
\text { cut2 }\end{array}$ & $\begin{array}{l}3.4302^{* * *} \\
(0.8472)\end{array}$ & - & $\begin{array}{l}7.1200 * * * \\
(0.9684)\end{array}$ & - & $\begin{array}{c}6.0115^{* * *} \\
(0.8557)\end{array}$ & - & - & - & - \\
\hline $\begin{array}{l}\text { Constant } \\
\text { cut3 } 3\end{array}$ & $\begin{array}{l}7.0305^{* * *} \\
(0.9074)\end{array}$ & - & $\begin{array}{l}9.8015^{* * *} \\
(1.0080)\end{array}$ & - & $\begin{array}{c}9.4683^{* * *} \\
(0.9681)\end{array}$ & - & - & - & - \\
\hline $\begin{array}{l}\text { Constant } \\
\text { cut } 4\end{array}$ & $\begin{array}{l}9.1884^{* * *} \\
(0.9329)\end{array}$ & - & - & - & - & - & - & - & - \\
\hline Pseudo R2 & 0.2130 & - & 0.1875 & - & 0.2402 & - & - & - & - \\
\hline Observations & 365 & - & 365 & - & 365 & - & - & - & - \\
\hline
\end{tabular}

Notes: Robust standard errors are placed in parentheses. ${ }^{* * *}$ indicates significance at the $1 \%$ level, ${ }^{* *}$ at the $5 \%$ level, and ${ }^{*}$ at the $10 \%$ level. Columns of Exp. present the values of exponentiated coefficients for Equations (1)-(3), respectively.

Our results, similar to the general findings of reviewed studies (Herreros and Criado [7]; Jones and colleagues [8,9]; Ruseva and colleagues [11]; Ziersch and colleagues [12]; Hoogerbrugge and Burge [13]; Jayashankar and Raju [14]; Daza [16]; Abrahamowicz [17]; 
Nowiński and Rialp [18] and Chen [19]), identify statistically significant positive associations between social capital variables and rural households' perceptions toward benefits of FCS projects. However, different from studies of Ziersch and colleagues [12] and Hoogerbrugge and Burge [13], our study finds no significant association between neighborhood relationship and rural households' perceptions about social, economic, and environmental benefits of FCS projects. One possible explanation for this result may be that the FCS projects in our study are externally funded and are less dependent on neighborhood relationship as compared to internally-funded and community-initiated projects. As revealed by Yang and colleagues' study, FCS projects which bring modern commercial culture to participating villages are inevitably and predominantly influenced by many external factors (i.e., carbon trading regulations, carbon prices, market competition, and availability of long-term funding support), in which case local households' participation is merely one of many elements which determine the success of project implementation [5]. In the light of the existence of multiple influencing factors which co-play during the project implementation period, farmers' perceptions about benefits of FCS projects are not that strongly dependent on neighborhood relationship because most of local farmers are involved in FCS projects as hired laborers and project land tenure holders who barely have decision power for the projects.

Our finding about the positive association between relationship with village officials and rural households' perceptions toward social, economic, and environmental benefits of the projects is somewhat supported by Chen's research which showed a positive influence of high-status networks, or in other words, relationship with powerful persons on respondents' perceptions of fairness [19]. This finding can be explained by the broadly-recognized phenomenon that in rural areas persons with power, especially political power, tend to have easier access to information and resources of projects being implemented [47-54], in which case households having a good relationship with powerful persons such as village officials are much more likely to benefit from the projects and consequently express more positive perceptions about project benefits.

In terms of the finding that members of local associations are more likely to have more positive perceptions toward social, economic, and environmental benefits of FCS projects, our result is similar to the result of Abrahamowicz which suggested that students who are members of student organizations tend to hold more positive perceptions toward academic performance and professional development [17]. Compared with non-members of local associations, members are more advantaged to get informed of project information in those associations. In such a case, member households tend to have easier access to more aspects of project information and obtain more knowledge about the project, based on which they are more likely to discern benefits of the project and subsequently form positive perceptions toward the benefits. Similarly, village-level public events play an essential role in gathering local residents and simultaneously circulating information about FCS projects, under which circumstance local households that are more frequently involved in village public events are more accessible to information about the projects and subsequently more likely to develop positive perceptions toward social, economic, and environmental benefits of the projects, which to some extent helps corroborate our finding that households' involvement in village public events is positively associated with their perceptions toward benefits of the projects, aligning with Chen's research result revealing that civic engagement exerts a positive impact on respondents' perceptions of fairness [19].

With respect to another interesting and surprising finding of our study that respondents from Yunnan Province are more likely to have negative perceptions toward social, economic, and environmental benefits of the project, one possible explanation is that sample areas located in Counties of Jinghong and Tengchong in Yunnan Province have many tourist attractions which are able to create a wide range of employment opportunities for local farmers, in which situation the FCS project may be less advantageous and less acceptable as compared to other competing tourism-related commercial projects which have higher job-generating and profit-making potential [4]. In such a case, attention of 
local households may be diverted from the FCS project, which may lead to biased views for the projects and then result in negative perceptions of local households toward benefits of the project.

\section{Conclusions}

Based on data collected from 450 rural households participating in forest carbon sequestration projects (FCS projects) in Sichuan and Yunnan Provinces, we examined the relationship between social capital and rural households' perceptions toward social, economic, and environmental benefits of FCS projects using the proportional odds model. Results suggested that: (i) the mean response levels for perceptions toward three types of benefits are significantly different, and households' perceptions toward environmental benefits are more positive than their perceptions toward economic benefits and social benefits, and their perceptions toward economic benefits are more positive than their perceptions toward social benefits, for both Provinces separately and combined; (ii) the mean response levels for all three benefits vary between 2.94 and 3.33, which indicates that the mean response levels for all three benefits are much lower than the highest possible level of 5; (iii) households reporting a good relationship with village officials have higher odds of holding more positive perceptions toward three types of benefits of FCS projects, whereas relationship with neighbors has no significant association with respondents' perceptions toward these benefits; (iv) households which are members of local associations are more likely to have better perceptions toward three types of benefits of FCS projects; (v) households whose members are more frequently involved in village-level public events are more likely to have better perceptions toward the benefits of FCS projects; (vi) households having more educated household heads have higher odds of holding better perceptions toward the benefits of FCS projects; and (vii) households from Yunnan Province as compared to Sichuan Province are less likely to express positive perceptions toward the benefits of FCS projects.

Based on the research results, some policy implications can be provided. Households' perceptions about social, economic, and environmental benefits are not necessarily the same, and therefore policies should incorporate specific features of different types of benefits. In order for FCS projects to be successfully implemented, local households' cooperation and support is crucial. As indicated by Dijksterhuis and Knippenberg's study which revealed that perceptions have a direct and persuasive influence on behaviors [30], whether farmers will cooperate with project developers and implementers depends much on their perceptions toward benefits of FCS projects. In other words, the more positive perceptions of farmers toward benefits of the projects, the higher acceptability for the projects and the higher possibility of choosing to cooperate. In this regard, the key to implementing FCS projects smoothly is to foster the formation of positive perceptions of local farmers, which can be specified as follows.

First, projects developers and implementers are advised to establish close and transparent collaborations with village officials, encouraging village officials to help publicize the projects in order to ensure that local farmers are well informed of the project information. Considering that village officials play important roles in shaping farmers' perceptions, village officials should be encouraged to maintain good relationships with local farmers throughout the project implementation period, which may positively influence farmers' opinions of the projects. Second, project implementers are highly encouraged to participate in events held by local farmer-centered associations, under which circumstance they can advertise the projects to members of associations and thereby get the project information circulated. Third, project implementers are also highly encouraged to co-organize villagelevel events with local organizers and incentivize villagers to participate in those events, in which case they can distribute project information to a broader audience. Last but not least, regularly broadcasting the projects via village radios is also a useful approach to getting local farmers well informed of the project updates and consequently facilitating the formation of positive perceptions toward benefits of the projects. 
Despite some useful policy implications, there are two limitations for our study. One limitation is that this paper merely considered four social capital elements consisting of relationship with neighbors, relationship with village officials, membership in local associations, and involvement in village public events on a yearly basis, without taking into account some other social capital compositions such as social network diversity, social trust and norms of reciprocity. The other limitation is that there is a lack of diversity for the chosen forest carbon sequestration projects, both of projects discussed in our study are afforestation and reforestation projects. If a larger number of social capital variables are included and a richer diversity of project types is considered, more inferences can be drawn on the basis of the research results. Despite the existing limitations, this study still creates fruitful avenues for future research. For instance, further research can extend to explore the impact of social capital on farmers' behaviors, considering a larger variety of social capital elements and more project types.

Supplementary Materials: The following are available online at https:/ / www.mdpi.com/2073-4 $45 \mathrm{X} / 10 / 2 / 91 /$ s1, a household questionnaire survey of rural households participating in the two FCS projects.

Author Contributions: Conceptualization, L.Q. and S.K.; methodology, L.Q. and S.K.; software, L.Q.; validation, L.Q., S.K. and S.W.; formal analysis, L.Q.; investigation, L.Q. and W.Z.; resources, W.Z.; data curation, W.Z.; writing—original draft preparation, L.Q.; writing—review and editing, S.K. and S.W.; supervision, S.K.; project administration, W.Z.; funding acquisition, W.Z. All authors have read and agreed to the published version of the manuscript.

Funding: This study was funded by the National Social Science Fund Project of China "Research on the Role of Forest Carbon Sequestration Projects in Poverty Alleviation in Ethnic Minority Areas of Southwest China" (Project No.15BJY093).

Data Availability Statement: Data used in this study will be available upon request from the first author.

Acknowledgments: We sincerely thank the survey team from Sichuan Agricultural University for their efforts in data collection. We also appreciate the helpful assistance from staff of Forest Departments of Sichuan and Yunnan Provinces who facilitated our questionnaire survey by helping summon local farmers. Additionally, we would like to say thanks to the local college students who provided translation services for us during the survey process. We are also very thankful to all respondents for their time, patience and efforts in answering questions. Without the cooperation of multiple participants mentioned above, our study will by no means be completed. Last but not least, we would like to say much thanks to three anonymous reviewers for their valuable suggestions and comments.

Conflicts of Interest: The authors declare no conflict of interest.

\section{References}

1. United Nation. Adoption of the Paris Agreement-Paris Agreement. Available online: Unfccc.int (accessed on 31 December 2020). (In English)

2. Zeng, W.Z.; Zhang, J.Y.; Yang, F. The role of forest carbon sequestration in poverty alleviation: Theoretical examination and practical considerations. Rural Econ. 2016, 5, 17-22. (In Chinese)

3. Zeng, W.Z.; Liu, S.; Yang, F.; Fu, X.H. An overview of literature about forest carbon sequestration from the poverty alleviation's point of view. Issues Agric. Econ. 2017, 2, 102-109. (In Chinese)

4. Qiu, L.L.; Yang, F.; Paudel, K.P.; Koondhar, M.A.; Zeng, W.Z. Influence of rural households' livelihood capital on income derived from participation in the Forest Carbon Sequestration Project: A case from the Sichuan and Yunnan Provinces of China. Int. For. Rev. 2018, 20, 538-558. [CrossRef]

5. Yang, F.; Paudel, K.P.; Cheng, R.; Qiu, L.; Zhuang, T.; Zeng, W. Acculturation of rural households participating in a clean development mechanism forest carbon sequestration program: A survey of Yi ethnic areas in Liangshan, China. J. For. Econ. 2018, 32, 135-145. [CrossRef]

6. Rakatama, A.; Iftekhar, M.S.; Pandit, R. Perceived benefits and costs of REDD+ projects under different forest management regimes in Indonesia. Clim. Dev. 2020, 12, 481-493. [CrossRef]

7. Herreros, F.; Criado, H. Social trust, social capital and perceptions of immigration. Political Stud. 2019, 57, 337-355. [CrossRef] 
8. Jones, N.; Evangelinos, K.; Halvadakis, C.P.; Iosifides, T.; Sophoulis, C.M. Social factors influencing perceptions and willingness to pay for a market-based policy aiming on solid waste management. Resour. Conserv. Recycl. 2010, 54, 533-540. [CrossRef]

9. Jones, N.; Evangelinos, K.; Gaganis, P.; Polyzou, E. Citizens' perceptions on water conservation policies and the role of social capital. Water Resour. Manag. 2011, 25, 509-522. [CrossRef]

10. Sandanam, A.; Diedrich, A.; Gurney, G.G.; Richardson, T.D. Perceptions of cyclone preparedness: Assessing the role of individual adaptive capacity and social capital in the Wet Tropics, Australia. Sustainability 2018, 10, 1165. [CrossRef]

11. Ruseva, T.B.; Farmer, J.R.; Chancellor, C. Networking for conservation: Social capital and perceptions of organizational success among land trust boards. Ecol. Soc. 2016, 21, 50. [CrossRef]

12. Ziersch, A.; Putland, C.; Palmer, C.; MacDougall, C.; Baum, F. Neighbourhood life, social capital and perceptions of safety in the western suburbs of Adelaide. Aust. J. Soc. Issues 2007, 42, 549-562. [CrossRef]

13. Hoogerbrugge, M.M.; Burger, M.J. Neighborhood-Based social capital and life satisfaction: The case of Rotterdam, the Netherlands. Urban Geogr. 2018, 39, 1484-1509. [CrossRef]

14. Jayashankar, P.; Raju, S. The effect of social cohesion and social networks on perceptions of food availability among low-income consumers. J. Bus. Res. 2020, 108, 316-323. [CrossRef]

15. Curry, K.A.; Holter, A. The influence of parent social networks on parent perceptions and motivation for involvement. Urban Educ. 2019, 54, 535-563. [CrossRef]

16. Daza, L. The role of social capital in students' perceptions of progress in higher education. Educ. Res. Eval. 2016, 22, 65-85. [CrossRef]

17. Abrahamowicz, D. College involvement, perceptions, and satisfaction: A study of membership in student organizations. J. Coll. Stud. Dev. 1988, 29, 233-238.

18. Nowiński, W.; Rialp, A. The impact of social networks on perceptions of international opportunities. J. Small Bus. Manag. 2016, 54, 445-461. [CrossRef]

19. Chen, M. Self-Assessed Health and Perceptions of Fairness in Metropolitan China: A Social Capital Perspective. Dev. Soc. 2016, 45, 411-438. Available online: https: / / www.jstor.org/stable/deveandsoci.45.3.411 (accessed on 1 March 2020). [CrossRef]

20. Torabi, N.; Cooke, B.; Bekessy, S.A. The role of social networks and trusted peers in promoting biodiverse carbon plantings. Aust. Geogr. 2016, 47, 139-156. [CrossRef]

21. Fischer, A.; Vasseur, L. Smallholder perceptions of agroforestry projects in Panama. Agrofor. Syst. 2020, 54, 103-113. [CrossRef]

22. Bozmoski, A.S.; Hultman, N.E. Participant perceptions of risk and benefit in carbon forestry: Evidence from central Tanzania. J. Environ. Dev. 2010, 19, 4-27. [CrossRef]

23. Lubell, M.; Hillis, V.; Hoffman, M. Innovation, cooperation, and the perceived benefits and costs of sustainable agriculture practices. Ecol. Soc. 2011, 16, 23. [CrossRef]

24. Bayrak, M.M.; Marafa, L.M. Livelihood implications and perceptions of large-scale investment in natural resources for conservation and carbon sequestration: Empirical evidence from REDD+ in Vietnam. Sustainability 2017, 9, 1802. [CrossRef]

25. Bourdieu, P. The Forms of Capital. Handbook of Theory and Research for the Sociology of Education, New York: Greenwood. 1986. Available online: http://www.socialcapitalgateway.org/sites/socialcapitalgateway.org/files/data/paper/2016/10/18 / rbasicsbourdieu1986-theformsofcapital.pdf (accessed on 1 March 2020).

26. Coleman, J.S. Foundations of Social Theory; Harvard University Press: Cambridge, MA, USA, 1994.

27. Putnam, R.D. Tuning in, tuning out: The strange disappearance of social capital in America. Political Sci. Politics 1995, 28, 664-683. [CrossRef]

28. Putnam, R.D. Making Democracy Work: Civic Traditions in Modern Italy; Princeton University Press: Princeton, NJ, USA, 1993. Available online: https:/ /dl1.cuni.cz/pluginfile.php/408189/mod_resource/content/1/Uvod\%20Robert\%20D\%20Putnam_ \%20-Making\%20democracy\%20work\%20_\%20civic\%20traditions\%20in\%20modern\%20Italy.pdf (accessed on 1 March 2020).

29. Wang, J.; Chang, H.; Li, W. Research on the Influence of Social Capital on the Entrepreneurial Performance in the Small MicroEnterprises. 2018. Available online: https://webofproceedings.org/proceedings_series/ESSP/SSAH\%202018/SSAH_0611215. pdf (accessed on 1 March 2020).

30. Dijksterhuis, A.; van Knippenberg, A. The relation between perception and behavior, or how to win a game of Trivial Pursuit. J. Pers. Soc. Psychol. 1998, 74, 865-877. [CrossRef]

31. Scrivens, K.; Smith, C. Four Interpretations of Social Capital: An Agenda for Measurement; OECD Statistics and Data Directorate: Paris, France, 2013. [CrossRef]

32. Seguin, R.A.; Sriram, U.; Connor, L.M.; Silver, A.E.; Niu, B.; Bartholomew, A.N. A civic engagement approach to encourage healthy eating and active living in rural towns: The HEART Club pilot project. Am. J. Health Promot. 2018, 32, $1591-1601$. [CrossRef]

33. Whitacre, B.E.; Manlove, J.L. Broadband and civic engagement in rural areas: What matters? Community Dev. 2016, 47, 700-717. [CrossRef]

34. Hoffman, K. Civic engagement at a small rural college: If we can do it ... . New Dir. Community Coll. 2016, 173, 93-102. Available online: https:/ / onlinelibrary.wiley.com/doi/pdf/10.1002/cc.20194 (accessed on 1 March 2020). [CrossRef]

35. Houston, D.; McKay, S.; Murray, M. Civic Engagement and Development Strategies: Learning from the Experience of Participatory Rural Redevelopment. Future Dir. Eur. Shrinking City 2016, 62-72. Available online: https:/ / www.routledge.com/products/9781 138814707 (accessed on 1 March 2020). 
36. Hurst, W.; Liu, M.; Liu, Y.; Tao, R. Reassessing collective petitioning in rural China: Civic engagement, extra-state violence, and regional variation. Comp. Politics 2014, 46, 459-482. [CrossRef]

37. Shortall, S. Are rural development programmes socially inclusive? Social inclusion, civic engagement, participation, and social capital: Exploring the differences. J. Rural Stud. 2008, 24, 450-457. [CrossRef]

38. Hofferth, S.L.; Iceland, J. Social Capital in Rural and Urban Communities 1. Rural Sociol. 1998, 63, 574-598. [CrossRef]

39. Oatley, K. Perceptions and Representations: The Theoretical Bases of Brain Research and Psychology; Routledge: London, UK, 2017. [CrossRef]

40. Ap, J. Residents' perceptions on tourism impacts. Ann. Tour. Res. 1992, 19, 665-690. [CrossRef]

41. Novartis. Novartis Carbon Sink Forestry Projects-Sichuan Forestry Project. pp. 10-11. Available online: https://www.novartis com/sites/www.novartis.com/files/novartis-carbon-sink-forestry-projects.pdf (accessed on 1 March 2020).

42. China Daily. Novartis Marks Its Eighth Year in Sichuan. Available online: http://www.chinadaily.com.cn/a/201812/20/WS5c1 b9e7ea3107d4c3a001f40.html (accessed on 1 March 2020).

43. The Climate, Community Biodiversity Alliance. CCB Standards ICCBA. Available online: https://www.climate-standards.org (accessed on 31 December 2020).

44. United Nations Framework Convention on Climate Change. CDM Afforestation and Reforestation Project Design Document. Available online: https://cdm.unfccc.int/Panels/ar/ARWG10_repan5_Form_AR_PDD.pdf (accessed on 1 March 2020).

45. Ma, Z.; Coppock, D.L. Perceptions of Utah ranchers toward carbon sequestration: Policy implications for US rangelands. J. Environ. Manag. 2012, 111, 78-86. [CrossRef] [PubMed]

46. O'brien, R.M. A Caution Regarding Rules of Thumb for Variance Inflation Factors. Qual. Quant. 2007, 41, 673-690. [CrossRef]

47. Iversen, V.; Chhetry, B.; Francis, P.; Gurung, M.; Kafle, G.; Pain, A.; Seely, J. High value forests, hidden economies and elite capture: Evidence from forest user groups in Nepal's Terai. Ecol. Econ. 2006, 58, 93-107. [CrossRef]

48. Pan, L.; Christiaensen, L. Who is vouching for the input voucher? decentralized targeting and elite capture in Tanzania. Policy Res. Work. Pap. 2012, 40, 1619-1633. [CrossRef]

49. Wen, T.J.; Yang, S. Rural governance and development under the background of social structure transformation in rural China. Theor. Investig. 2012, 6, 76-80. (In Chinese)

50. Lund, J.F.; Saito-Jensen, M. Revisiting the issue of elite capture of participatory initiatives. World Dev. 2013, 46, 104-112. [CrossRef]

51. Xing, C.J.; Li, X.Y. A study on elite capture and the deviation from financial poverty alleviation goals. Chin. Public Adm. 2013, 9 , 111-115. (In Chinese)

52. Platteau, J.P.; Somville, V.; Wahhaj, Z. Elite capture through information distortion: A theoretical essay. J. Dev. Econ. 2014, 106, 250-263. [CrossRef]

53. Liang, J.F.; Li, J. Elite capture: The plights of farmer cooperatives. Macroeconomics 2015, 3, 58-62. (In Chinese)

54. Cheng, M.; Zheng, Y.F.; Xu, J.X.; Chen, N.D. On the predicament of elite capture in participatory poverty alleviation and governance and the corresponding countermeasures. Rural Econ. 2017, 9, 56-62. (In Chinese) 